\title{
Neu-Laxova syndrome
}

INSERM

\section{Source}

INSERM. (1999). Orphanet: an online rare disease and orphan drug data base. NeuLaxova syndrome. ORPHA:2671

Neu-Laxova syndrome (NLS) is a rare, multiple malformation syndrome characterised by severe intrauterine growth retardation (IUGR), severe microcephaly with a sloping forehead, severe ichthyosis (collodion baby type), and facial dysmorphism. 